(aged 24-50) were then visited without prior warning and their height and weight measured. Their reported heights and weights were on average 0.5 in $(12.7 \mathrm{~mm})$ above and $6.1 \mathrm{lb}(3.13 \mathrm{~kg})$ below their actual measurements. As in Ashwell and Etchell's paper, overweight was assessed using the Metropolitan Life Insurance Company tables. ${ }^{2}$ For $90 \%$ of the women the reported measurements indicated a lower degree of overweight than the actual measurements, the difference being roughly proportional to the degree of overweight.

As well as broadly classifying body size as either "overweight," "suitable," or "underweight" Ashwell and Etchell define categories of over- and underweight. Individuals $30 \%, 20 \%$, and $10 \%$ above ideal weight were classed as severely, moderately, and mildly overweight respectively, with corresponding groupings for underweight. Using these categories 15 of the $\mathbf{4 0}$ women in our study were classified in a lower category on reported than on actual measurements. Four of these changes were from the broad classification "overweight" to that of "suitable weight."

Our data indicate that reported height and weight should be treated with great caution, as there appears to be systematic underestimation of body size. It may well be that this underestimation of body size as assessed from reported data reflects awareness of overweight status. We would suggest that any further studies on perception of overweight should obtain information on reported as well as actual height and weight and also perceived weight status.-We are, etc.,

DOUglas ALtMaN LESLIE IRWIG

Department of Community Medicine,

London S.E.1 1 Ashwell, M., and Etchell, L., British foumal of Bulletin, 1959, 40, Nov.-Dec.

\section{SI Units}

SIR,-If and when SI units are introduced into clinical praotice I foresee very real difficulties in the management of patients. Apart from the expense involved in converting to SI, the management of common diseases is surely going to be very much more difficult. When one is informed that a patient in diabetic ketoacidosis has a blood sugar of $780 \mathrm{mg} / 100 \mathrm{ml}$ one has an instant picture of whet that patient's clinical state is likely to be. The SI unit normal range of blood sugar is $3.0-5.0 \mathrm{mmol} / \mathrm{l}$ and we are told that the approximate range found in hospital practice could vary from 0.6 to 60 $\mathrm{mmol} / 1$. It will not be easy to decide on insulin dosage in such patients. I would think that the same difficulties would arise in uraemic patients when the blood urea is measured in SI units.

We are told that prescribing will not be changed to SI; neither will bilood pressure recordings. These have presumably been left alone because of expediency. I think many practising dinicians would feel that much the same argument could be applied to many of the parameters routinely measured in blood ohemistry and that to introduce a completely new set of values at this time, when the Health Service is in dire trouble, will not help in the management of patients.

There is still doubt that the Americans will go over to SI units and this must mean that the American and British medical literature will be in two completely different sets of units. Medicine is not a science; is empiricism now a dirty word?-I am, etc.,

Department of Medicine,
Good Hope General Hospital

B. H. BASS

\section{Tafracher}

SIR,-I was most interested in Dr. F. I. D. Konotey-Ahulu's Personal View of the Ghanaian word tafracher (8 February, p. 329). Though English has no direct equivalent the sentiment has not, at least in the past, been foreign to us, as is witnessed by the expression of an Irish woman describing the death of her daughter's ahild to $\mathrm{my}$ father some years ago: ". . . and then, saving your presence, his little bowels gave way."-I am, etc.,

D. S. THOMPSON

London N.19

*** We have received several letters drawing attention to similar expressions in use in a variety of languages and cultures.-ED., B.M.f.

\section{Comparison between Free Thyroxine Index and Effective Thyroxine Ratio}

SIR,-We read with great interest the paper by Dr. E. G. M. D'Haene and others (21 September, p. 708) on the comparison of the Mallinckrodt effective thyroxine ratio (E.T.R.) with the serum free thyroxine index (F.T.I.). Using Spearman's rank correlation analysis, the authors found a highly significant relationship between the E.T.R. and the F.T.I., with a correlation coefficient of 0.68 . The correlation $c^{0}-$ efficient was considerably less than that found by us-namely, 0.95-when we used the Pearson product-moment correlation coefficient in a study of three groups of patients classified as hypothyroid, euthyroid, and hyperthyroid. 1 A similar correlation $\infty^{-}$ efficient (0.93) was found between the E.T.R. and the free thyroxine concentration (F.T.C.). We found it necessary to select patients and subjects in order to yield diagnostic groups of approximately equal numbers. This leads to a much more sensitive repression analysis because of the wider spread of values.

Dr. D'Haene and his colleagues, however, consider that if a given variable has a normal distribution in the population it is necessary, in assessng the variable, to select test subjects (or specimens) by random sampling and hence are critical of our statistical handling of our data. However, we submit that their approach, which studies a randomly selected group of subjects, has no application in the regression model used by us. The essential point in the design is the random distribution of assay errors and not of the population from which the specimens were collected.

It seems that these authors have confused regression with correlation analysis. As pointed out by Hays, ${ }^{2}$ each is appropriate to a particular kind of research enterprise. Correlation analysis applies especially to problems of prediction. Regression analysis on the other hand determines the relationship between a set of variables-for example, does the E.T.R. increase as the F.T.I. increases and, if so, is there a mathematical rule which describes the relationship? Dr. D'Haene and his colleagues have found a poorer correlation between E.T.R. and F.T.I. because $70-75 \%$ of their specimens had normal values and because the E.T.R. has a very low coefficient of variation (C.V.) (3.7\% in our hands) in euthyroid subjects. Furthermore, they would have encountered a substantial number of multiple tied values, which would also detraot from the degree of correlation found, and there is no indication in their paper that they have corrected for ties.

Further studies from our laboratory ${ }^{3}$ have indicated that the E.T.R. is a good screening technique, as in euthyroid patients with low activity of thyroxine-binding proteins the diagnostic accuracy of the E.T.R. $(80.5 \%)$ is superior to that of the F.T.I. $(62.5 \%)$ and F.T.C. $(67 \%)$. In euthyroid patients with elevated thyroxine-binding proteins the diagnostic accuracy of E.T.R. is 93.5\% compared with $83 \%$ for F.T.I. and 91\% for F.T.C.

Though the conclusion of Dr. D'Haene and his colleagues that the E.T.R. is not a satisfactory substitute for the F.T.I. is probably inoorrect in the light of our studies, we do agree that there are some limitations in the E.T.R., as continuing studies in our laboratory have demonstrated. It is not a good parameter to use in patients undergoing triiodothyronine ( $T-3)$ suppression, nor is it a good assay in either thyroidstimulating hormone (T.S.H.) or thyroxinereleasing hormone stimulation tests. Furthermore, the very low C.V. of the E.T.R. may indicate relative insensitivity rather than a high degree of precision. This leads to a marked overlap in values between clinically hypothyroid patients and normal subjects, particularly where treatment has been given for thyroid disorders. In clinical situations, such as that following radioiodine treatment, it is mandatory to use serum assays such as T.S.H. and T-3 concentration to supplement the E.T.R. test.-We are, etc.,

M. L. WELLBY M. W. O'HALLORAN JaNET Marshall.

Department of Clinical Chemistry,

The Queen Blizabeth Hospit

1 Wellby, M. L., O'Halloran, M. W., and Marshall, 2 J., Clinica Chimica Acta, 1973, 45,255 .

P. 536. New York, Holt, Rinehart and Winston, Wellby, M. L., O'Halloran, M. W., and Marshall, J., Clinical Endocrinology, 1974, 3, 63 .

\section{Venous Gangrene in Multiple Myeloma}

SIR,-The incidence of thromboembolism in myelomatosis based on a preliminary estimate of 376 patients admitted to the Medical Research Council's myelomatosis trial up to March 1970 was reported to be about 3\%, but the incidence of gangrene of the feet as a presenting feature is uncommon. Catovsky et al..$^{1}$ reported 14 cases of myelomatosis associated with major 
thromboembolic complications: six patients died of pulmonary embolism, seven had deep vein thrombosis as a presenting symptom, and three had evidence of amyloidosis. We report here a case of multiple myeloma presenting as venous gangrene of feet.

A 71-year-old woman presented with bilateral deep venous thrombosis, gangrene of her right foot, and a pregangrenous state of her left foot. She was drowsy, dehydrated, and hypothermic. Her peripheral arterial pulsations were normal, but she had swelling of both calves, which were warm and tender, and all five toes of the right foot were black and gangrenous.

The urine contained $2.8 \mathrm{~g} / 1(280 \mathrm{mg} / 100 \mathrm{ml})$ protein and more than 100 pus cells per field. I was positive for Bence Jones protein. Her blood urea on admission was $86 \mathrm{mmol} / 1$ ( $518 \mathrm{mg} / 100 \mathrm{ml})$, haemoglobin $14.8 \mathrm{~g} / \mathrm{dl}$, and leucocyte count $54.9 \times$ $10^{9} / 1\left(54900 / \mathrm{mm}^{3}\right)$, with $91 \%$ neutrophils, $6 \%$ lymphocytes, and $3 \%$ monocytes, but no immature cells. Blood film showed red cell rouleaux forcells. Blood film showed red cell rouleaux for-
mation. The platelet count was $315 \times 10^{9} / 1$ mation. The platelet count was $315 \times 10^{9 / 1}$
$\left(315,000 / \mathrm{mm}^{3}\right)$ and E.S.R. $63 \mathrm{~mm}$ in $1 \mathrm{~h}$. The total plasma protein concentration was $97 \mathrm{~g} / \mathrm{l}(0 \cdot 7 \mathrm{~g} / 100$ plasma protein concentration was $97 \mathrm{~g} / \mathrm{l}(9 \cdot 7 \mathrm{~g} / 100$
$\mathrm{ml})$, albumin $22 \mathrm{~g} / \mathrm{l}(2.2 \mathrm{~g} / 100 \mathrm{ml})$, and globulin $\mathrm{ml})$, albumin $22 \mathrm{~g} / 1(2 \cdot 2 \mathrm{~g} / 100 \mathrm{ml})$, and globulin $75 \mathrm{~g} / \mathrm{l}(7 \cdot 5 \mathrm{~g} / 100 \mathrm{ml})$. Serum protein electrophoresis showed grossly increased $\gamma$-globulins with a
sharply defined band of abnormal protein in the $\beta$ position on starch gel electrophoresis. Serum immunoelectrophoresis showed the paraproetin to be an IgG and transferrin was reduced. O immunodiffusion IgG was shown to be increased to $68 \mathrm{~g} / 1(6800 \mathrm{mg} / 100 \mathrm{ml}$ ) (normal $8-16 \mathrm{~g} / \mathrm{l})$, IgA $1.1 \mathrm{~g} / 1(110 \mathrm{mg} / 100 \mathrm{ml}$ ) (normal $0.9-4.5 \mathrm{~g} / \mathrm{l})$, and IgM $0.34 \mathrm{~g} / 1(34 \mathrm{mg} / 100 \mathrm{ml}$ ) (normal $0 \cdot 6-2 \cdot 8 \mathrm{~g} / \mathrm{l}$ ) The Sia test for macroglobulins was negative and no cryoglobulins were detected. Bone marrow no cryoglobulins were detected. Bone marrow examination showed a marked increase in mature plasma cells with depressed erythropoiesis, and the haemoglobin level later dropped to $7.9 \mathrm{~g} / \mathrm{dl}$. Serum calcium was normal at $2.45 \mathrm{mmol} / \mathrm{l}(9.8 \mathrm{mg} / 100 \mathrm{ml})$ but serum phosphate was increased to $2.5 \mathrm{mmol} /$ $(7.8 \mathrm{mg} / 100 \mathrm{ml})$ owing to renal failure. Serum urate was $79 \cdot 7 \mathrm{mmol} / 1(13.4 \mathrm{mg} / 100 \mathrm{ml})$. Skeletal survey, which included $x$-rays of chest, pelvis upper femora, skull, mandible, humeri, and dorsolumbar spine, showed no evidence of myeloma.

On intravenous fluids her blood urea began to fall and with further treatment it dropped to $8.9 \mathrm{mmol} / 1(54 \mathrm{mg} / 100 \mathrm{ml})$. She was treated with intermittent courses of melphalan and prednisolone with complete disappearance from her urine of Bence Jones protein. The total plasma protein Bence Jones protein. The total plasma protein
dropped to $73 \mathrm{~g} / 1(7 \cdot 3 \mathrm{~g} / 100 \mathrm{ml})$, albumin $32 \mathrm{~g} / 1$. dropped to $73 \mathrm{~g} / 1(7 \cdot 3 \mathrm{~g} / 100 \mathrm{ml})$, albumin $32 \mathrm{~g} / 1$
$(3 \cdot 2 \mathrm{~g} / 100 \mathrm{ml})$, and globulin $41 \mathrm{~g} / 1(4 \cdot 1 \mathrm{~g} / 100 \mathrm{ml})$
and the electrophoretic band due to abnormal protein became faint. IgG fell to $36 \mathrm{~g} / \mathrm{l}$ (3600 protein became faint. IgG fell to $36 \mathrm{~g} / 1$ (3600 $\mathrm{mg} / 100 \mathrm{ml})$. The
in her gangrene.

The incidence of venous gangrene in multiple myeloma is rare and it is interesting to note the remarkable improvement of the gangrene in this elderly woman with the treatment of multiple myeloma alone and without any surgical intervention. In view of the good arterial supply to the feet the superficial gangrene was attributable to occlusion of venules associated with the high level of IgG and hypothermia.-We are, etc.

A. N. Chatterj

St. Albans City Hospital

G. H. APTHORP 1 Catovsky, D., et al., British Medical fournal

\section{Illness in the Clouds}

SIR,-Your leading article (8 February, p. 295) has caused me some disquiet. I travel not infrequently by air and am therefore one of the doctors who may be expected on statistical grounds to be available in an emergency. As a miorobiologist engaged for the past 10 years in administration, this prospect fills me with no enthusiasm. Can anyone advise me on how to prepare for it? Do I need to carry an emergency kit, go on a course, and carry extra international insurance? On reflexion, I shall avoid air travel where possible-and also reading the B.M.f.! - I am, etc.

London N.W.9

J. C. KeLSEY

\section{New Causes of Malignant Hyperpyrexia}

SIR,-Dr. J. A. Lack (4 January, p. 36) raised the possibility of inadvertent adminis tration of halothane to a patient who developed malignant hyperpyrexia with nitrous oxide. ${ }^{1}$ He pointed out that halothane would be present in the gas delivered from most anaesthetic machines due to halothane liberated from rubber breathing tubes, etc. Other sources of contamination have been found such as elastomeric seals and certain rigid plastics within anaesthetic apparatus.

As we were aware of this danger we took the following precautions: (1) the vaporizer was removed from the machine (a conventional B.O.C. Mk II Boyle's machine); (2) all rubber tubing, rubber connexions, and mask were brand new; and (3) the machine was purged with a nitrous oxide/oxygen gas mixture at a flow rate of $8 \mathrm{l} / \mathrm{min}$ for about 30 minutes before induction of anaesthesia. It could be argued that even with these precautions enough halothane could still be present to induce malignant hyperpyrexia. However, during the third anaesthetic given to the patient, which consisted of thiopentone without nitrous oxide, oxygen was administered from the same machine and no pyrexia occurred. A second patient, the above patient's homozygous twin, received a thiopentone/oxygen anaesthetic similarly with no rise in temperature.

There is a potential danger to patients highly susceptible to halothane in leaving the vaporizer on the machine even though it is in the "off" position. On a hot morning in June 1973 we anaesthetized a third patient susceptible to malignant hyperpyrexia using an anaesthetic machine with the halothane vaporizer (Fluotec Mk II) in the "off" position. The patient developed a low-grade pyrexia towards the end of the procedure, which had lasted $1 \frac{1}{2}$ hours, and on investigation a faint smell of halothane vapour was detected in the gas mixture. A Hook and Tucker ultraviolet halothane meter indicated that a low but measurable concentration of halothane was present (less than $0.25 \%$ v/v). Professor J. S. Robinson and his colleagues in the University of Birmingham investigated our suspect vaporizer in their laboratory under similar conditions and found that there was a constant leak of halothane vapour of between 4 and 9 p.p.m. v/v. However, when the gas flow was first turned on comparatively high levels of halothane vapour were delivered; initial concentrations were well in excess of 123 p.p.m. $v / v$ and fell rapidly to 10 p.p.m. $v / v$ after 15 minutes. The effect of a rising ambient temperature (as we had experienced during the anaesthetic) was to almost double the constant leak. Professor Robinson and his colleagues have described their analytical technique. ${ }^{3}$

In the light of more recent experience it is impossible to know whether the low grade pyrexia in the third patient was due to nitrous oxide, low concentrations of halothane, both these drugs acting together, or other cause. When anaesthetizing a patient thought to be highly susceptible to halothane for any reason it would be sensible to take the precautions outlined above. We now use Cyprane equipment comprising a Quantiflex gas mixer, single vaporizer Selectatec back bar, and a conventionaR Magill attachment. No vaporizer has eve $\mathbb{8}$ been fitted to this equipment and we fee! that the inadvertent administration of halothane or other anaesthetic vapours is? virtually impossible.-We are, etc.,

F. RICHARD ELLIS

I. M. C. Clark而

E. M. MODGILI

Malignant Hyperpyrexia Investigation Unit,

University Department of Anaesthesia,

T. N. APPLEYARY

R. C. W. DINSDALE

Departments of Anaesthesia and School of Dentistry, University of Sheffield,

1 Ellis,

4, 270. R., et al., British Medical fournal, 1974 if Robinson, J. S., Thompson, J. M., and Barratt, R. S. Personal communications. R. S., British Medical fournal, 1974, 3, 515 .

Changing from a High- to Low-dose Oral Contraceptive

SIR,-The trend towards reducing the steroid content of combined-type oral con $\overrightarrow{0}$ traceptives continues, and products containing $20-40 \mu \mathrm{g} /$ day ethynylestradiol are now available or on trials in many countries. ${ }^{1}$ it In the hope of reducing adverse side effects 5 of oral contraceptives many practitioners wilb transfer patients to these new products. An important problem for suah women is to determine whether the sudden reduction in dose is associated with "escape" ovulations during the first cycle of treatment with $a^{\mathrm{P}}$ low-dose preparation.

We have investigated this problem in $10 \overline{0}$. healthy young women who were switcheds from high-dose products (Gynovlar (3 mgs norethisterone acetate $+50 \mu \mathrm{g}$ ethynylestradiol) or Nordiol (250 $\mu \mathrm{g}$ D-norgestrel $+\frac{O}{3}$ $50 \mu \mathrm{g}$ ethynylestradiol)) to a new low-dose preparation, Nordette (150 $\mu \mathrm{g}$ D-norgestreb $+30 \mu \mathrm{g}$ ethynylestradiol). Venous blood specimens were collected daily during theo first treatment cycle following the change in medication. Plasma progesterone and lutein-0 izing hormone (LH) were measured by specific radioimmunoassays. Progesterone concentration did not exceed $0.9 \mu \mathrm{g} / 1$ in any specimen, while $\mathrm{LH}$ concentration remaineक below $21 \mathrm{IU} / 1$

We conclude that transferring patients from a high-dose oral contraceptive to one containing only $30 \mu \mathrm{g}$ ethynylestradiol perD day is not likely to allow escape ovulations? during the first cycle with the new product. 0 It would therefore seem unnecessary too advise the use of additional contraceptive precautions to patients who make this change in oral contraceptive preparations? -We are, etc.

MICHAEL BRIGgS?

Gordon Institute, MAXINE BRIGGS

Current Medical Research and Opinion, 1974, 2, 95. Schneider, W., Spona, J., and Matt, K., Contra-
ception, 1974, 9, 81. 